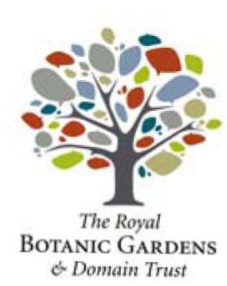

plantnet.rbgsyd.nsw.gov.au/Telopea • escholarship.usyd.edu.au/journals/index.php/TEL •ISSN 0312-9764 (Print) •ISSN $2200-4025$ (Online)

Telopea 1 (1): $40-43$ (1975).

\title{
CONTRIBUTIONS TO THE TAXONOMY OF AUSTRALIAN GRASSES IIII
}

\author{
JOYCE W. VICKERY
}

(Received May 1974)

\section{ABSTRACT}

Vickery, Joyce W., (National Herbarium of New South Wales, Royal Botanic Gardens, Sydney, New South Wales, Australia) 1975. Contributions to the Taxonomy of Australian Grasses III. Telopea 1 (I): 40-43.-The following new taxa are described: Paspalidium breviflorum Vickery, Setaria paspalidioides Vickery and Microlaena stipoides var. breviseta Vickery.

\section{PASPALIDIUM}

Paspalidium breviflorum Vickery, sp. nov.

Gramen perenne gracillimum adscendens. Culmi geniculati ramosi tenues imbecilles striati glabri laeves circa $40 \mathrm{~cm}$ longi latero uno canaliculati, saepe ad nodos inferiores radicantes. Nodi glabri. Vaginae quam internodos breviores carinatae, laeves, striatae, margine uno et collo ciliatae alioquin glabrae. Ligula vix $0.5 \mathrm{~mm}$ longa, ciliata. Laminae anguste lineares, in apices acuminatos attenuatae, tenues planae usque ad $9 \mathrm{~cm}$ longae et $3.5 \mathrm{~mm}$ latae, glabrae, tenuiter nervatae nervo medio manifestiusculo, in nervis praesertim superficie subtiliter scabridae. Inflorescentia tandem valde exserta, angustissima, axe primario triquetro scabridoque, racemos usque ad 10 appressis gerente, racemis inferioribus $0.5-1.5$ $\mathrm{cm}$ longis quam internodos valde brevioribus, superioribus gradatim brevioribus et magis approximatis, unoquoque seta $1-2 \mathrm{~mm}$ longa gracili terminato, rhachide triquetra flexuosa angulis scabris, circa $0.4 \mathrm{~mm}$ lato, secundo spiculas alternatas bifariam gerenti, pedicellis $0.25-0.5 \mathrm{~mm}$ longis ad apices disciformibus. Spiculae 1.8-2 $\mathrm{mm}$ longae, $1.2-1.3 \mathrm{~mm}$ latae, ad medium latissimae, subrotundatae pallidae, plus minusve obtusae sed minute apiculatae, aggregatae imbricataeque a rhachide divergentes. Gluma inferior membranacea, usitatis vix ad medium spiculae aequans, subacuta, latissime oblata, basi inflata, basem spiculae amplectens. Gluma superior textura simulans, convexissima, $\frac{7}{8}$ spiculae aequans, rotundata obtusissima minute apiculata, manifeste 7-9-nervata, nervis subparallelis prope apicem anastomosantibus. Flosculus inferior neuter; Lemma spiculam subaequans, textura glumas simulans, obtusum minute apiculatum in dorso non profunde sulcatum, 5-nervatum nervis ad apicem anastomosantibus; palea parva membranacea vel absens. Flosculus superior hermaphroditus planoconvexus gibbosus: Lemma spiculam aequans, crustaceum striolatum, medium versus grosse transverse rugulosum, ad basim areola manifestissima laeviore, latissime ellipticum, apiculatum, margines paleae amplectens; palea in dorso plano textura lemma simulans, lateribus laevis nitidaque prope medium lobis marginalibus latioribus.

Holotype: New South Wales: North Coast: Richmond River, per Messrs. Foster \& Sons NSW 8946, 5.1912 (NSW).

Very slender, ascending perennial. Culms geniculate, branching, often rooting at the lower nodes, thin, weak, striate, glabrous, smooth, about $40 \mathrm{~cm}$ long. Nodes glabrous. Sheaths shorter than the internodes, keeled, smooth, ciliate along one margin and at the collar, otherwise glabrous. Ligule divided into a dense row of short cilia, scarcely $0.5 \mathrm{~mm}$ long altogether. Blades narrowly linear, 
tapering to an acuminate apex, thin, flat, up to $9 \mathrm{~cm}$ long and $3.5 \mathrm{~mm}$ wide, finely nerved with a rather distinct midrib, glabrous, finely scabrid on the nerves especially on the upper surface. Inflorescence very narrow, the main axis more or less triquetrous and scabrid, bearing up to 10 racemes, the lower $0.5-1.5 \mathrm{~cm}$ long and much shorter than the internodes between them, the upper gradually shorter and more approximate, each terminated by a slender $1-2 \mathrm{~mm}$ long bristle, the rhachis triquetrous, flexuose, scabrous on the angles, about $0.4 \mathrm{~mm}$ wide, the spikelets borne in 2 alternate rows on one side of the rhachis on $0.25-0.5 \mathrm{~mm}$ long pedicels with discnid apices. Spikelets $1.8-2 \mathrm{~mm}$ long, $1.2-1.3$ $\mathrm{mm}$ wide, broadest at the middle, rotundate, more or less obtuse but minutely apiculate, pallid, very crowded with each much overlapping the base of the one above, obliquely divergent from the rhachis. Lower glume usually less than half the length of the spikelet, subacute, inflated at the base at least at maturity, very broadly oblate, embracing the base of the spikelet, 3-nerved with the nerves confluent near the apex. Upper glume very convex, about seven-eighths as long as the spikelet, rotundate, very obtuse, minutely apiculate, prominently 7 - to 9-nerved with the nerves subparallel, anastomosing near the apex. Lower floret sterile: Lemma subequal to the spikelet in size and outline, obtuse, minutely apiculate, shallowly furrowed down the back, 5-nerved with the nerves anastomosing at the apex; palea small or absent. Upper floret planoconvex, gibbous: Lemma as long as the spikelet, crustaceous, striolate, very coarsely transversely rugulose about the middle with a very distinct smoother areole at the base, very broadly elliptical, apiculate, embracing the margins of the palea; palea similar in texture to the lemma on the flat back, smooth and shining on the sides.

Distribution: The only other specimen I have seen was collected in New England (NSW 8937), a district name which at the time of collection could have included both Tablelands and Coast. From the late Dr S.T. Blake I have learned that this species also occurs in Queensland.

Dr Blake drew attention to this species when, in 1956, he attached labels bearing the above name to the two specimens in the New South Wales National Herbarium cited above. My own subsequent examination of the specimens led me to agree that they represented a species distinct from any other that occurs in this State and I drew up a description for the Flora of New South Wales in the hope that meanwhile he would formally name the species. In a letter dated 12.2.1969 Dr Blake wrote "T have had a few misgivings about P. breviflorum because of the variability in foliage and now I find specimens from Hawaii that seem fairly similar but I have not gone into this properly". In view of these expressed doubts and the absence of any clearly identifiable comment on the species in his posthumous paper in Proc. Roy. Soc. Queensland 84: 61-70 (1973), T have reluctantly felt that $I$ should take sole responsibility for publication of the name.

One cannot be sure from Blake's comments on p. 68 regarding the occurrence of "unusually short but not narrower and therefore relatively broader" spikelets of some specimens of $P$. aversum and $P$. radiatum whether he intended to include specimens of $P$. breviflorum. However, $P$. radiatum can be clearly distinguished from $P$. breviflorum by its more finely rugulose fertile floret, while $P$. aversum differs from it in the size and shape of the spikelets and fertile florets and the more widely spaced nervation of the upper glume. In shape the spikelet of $P$. breviflorum is rather similar to the spikelet in the illustration (P1. VII, fig. 5) of $P$. scabrifolium S.T. Blake but $P$. breviflorum differs from that species in its narrower and scarcely scabrous leaves and somewhat smaller spikelets, and Blake states that $P$. scabrifolium is known only from brigalow country in the Port Curtis district. 


\section{SETARRA}

Setaria paspalidioides Vickery, sll nov.

Gramen perenne caespitosum usque ad $70 \mathrm{~cm}$ altum. Culmi valde compressi, valde costati, praesertim sursum nodos versus scabri, latere uno canaliculati, glabri. Nodi glabri vel sparse minutissimeque pubescentes, nigelli. Vaginae compressae, sursum carinatae, manifeste costatae, scabrae, margine uno longe ciliato, pilis longis tenuibus albidis basi manifeste tubercularibus adspersae. Ligula dense ciliata circa $1.5 \mathrm{~mm}$ longa. Laminae planae lineares paullo basin versus angustatae, sursum in apices acuminatos diminutae, firmae rigidiusculae usque ad $30 \mathrm{~cm}$ longae et $9 \mathrm{~mm}$ latae, scabrae, praesertim in paginis superioribus pilis basi tubercularibus adspersae, marginibus scabris, subter nervo medio manifesto, ejus in quoque latere utrimque circa 6 nervis primariis. Panicula tandem longe exserta pedunculo praesertim sursum scabro, angusta, spiculis sparsiuscule et laxe instructa, spiculis nonnullis in ramis erectis distantiusculis basin versus usque ad $2.4 \mathrm{~cm}$ longis sed apicem versus longitudine diminutis, axe primario angulare dense scabro vel scabro-pubescenti, ramis tenuibus flexuosis compressis scabropubescentibus, spiculas in fasciculis parvis vel solitarias gerentibus, spiculis multis vel paucis seta una subtentis, setis inaequalibus flexuosissimis usque ad $10 \mathrm{~mm}$ longis erectis antrorse scabris inconspicuis. Spiculae brevissime pedicellatae, elliptico-obovatae subacutae circa $3 \mathrm{~mm}$ longae et $1.6-1.7 \mathrm{~mm}$ latae, in latere uno turgido-gibbosae pallidae glabrae, glumis lemmateque inferiore membranaceochartaceis nervis prominulis. Gluma inferior basi inflata, late triangularis acuta vel obtusa, 5-nervata, longitudine circa $\frac{2}{3}$ spiculae partes aequans. Gluma superior latissime elliptica vel rotundata in dorso convexissima, primum longitudine circa $\frac{5}{6}$ spiculae partes aequans sed tandem circa flosculum fertilem maturescentem retracta et tum longitudine circa $\frac{3}{5}$ spiculae partes aequans plus minusve obtusa 7-9-nervata. Flosculus inferior neuter: Lemma spiculam aequans late acutum apiculatum 5-nervatum in dorso planum vel depressum; palea hyalina lanceolata, longitudine $\frac{3}{4}$ lemmatis partes aequans. Flosculus superior hermaphroditus flosculum inferiorem aequans unilateraliter turgidissimus late acutus minute apiculatus: Lemma crustaceum, subtus grossiuscule dulceque transverse rugulosum, laeve in quarta parte superiore, nitidum, in maturitate aureo-brunneum, in dorso convexissimum vel convexo-gibbosum; palea lemma subaequans, in dorso plana vel basem versus aliquanto turgida, crustacea in dorso quam lemma paullo tenuiore rugulosa, lateribus laevibus curvatis nitentibus florem amplectentibus. Caryopsis latissime ovata-elliptica turgida planoconvexa vel in dorso paullo depressa, circa $1.75 \mathrm{~mm}$ longa et $1.25 \mathrm{~mm}$ lata, embryone longitudine circa $\frac{2}{3}$ caryopsidis partes aequanti, hilo late ovali-punctiforme.

Holotype: New South Wales: Western Plains: Gulargambone, E.C. Mathes NSW 9027, 27.iv.1936 (NSW).

Tufted perennial up to $70 \mathrm{~cm}$ high. Culms strongly compressed, strongly ribbed, scabrous especially upwards towards the nodes, channelled on one side, glabrous. Nodes glabrous or sparsely minutely pubescent, blackish. Sheaths compressed and keeled upwards, prominently ribbed, scabrous, long-ciliate on one margin, sprinkled with long, fine, white, manifestly tubercle-based hairs. Ligule densely ciliate, about $1.5 \mathrm{~mm}$ long altogether. Blades flat, linear, slightly narrowed towards the base, tapering upwards to an acuminate point, firm, rather stiff, up to $30 \mathrm{~cm}$ long and $9 \mathrm{~mm}$ wide, scabrous, sprinkled especially on the upper surface with tubercle-based hairs, the margins scabrous, the midrib prominent below, with about 6 primary nerves on each side of it. Panicle at length long-exserted on a peduncle scabrous more or less throughout but especially upwards, narrow, rather sparsely and loosely flowered with spikelets several on rather distant, erect branches up to $2.4 \mathrm{~cm}$ long near the base diminishing in length towards the apex, the main axis angular, closely scabrous to scabrous- 
pubescent, the branches slender, flexuose, compressed and similarly scabrouspubescent, bearing small clusters of or single spikelets on very short pedicels with discoid tips, many but not all of the spikelets subtended by a bristle, the bristles unequal, very flexuose, up to about $10 \mathrm{~mm}$ long, erect, antrorsely scabrous, not very conspicuous on the panicle. Spikelets elliptical-obovate in outline, subacute, about $3 \mathrm{~mm}$ long and $1.6-1.7 \mathrm{~mm}$ wide, turgid-gibbous on one side, pallid, glabrous, the glumes and lower lemma membranous-chartaceous with moderately prominent nerves. Lower glume inflated at the base, broadly triangular, acute to obtuse, about two-fifths as long as the spikelet, 5-nerved. Upper glume very broadly elliptical or rotundate, very convex on the back, at first about five-sixths as long as the spikelet, but when retracted around the maturing fertile floret then appearing about three-fifths as long, more or less obtuse, 7- to 9-nerved. Lower floret sterile: Lemma as long as the spikelet, broadly acute, apiculate, flat or depressed on the back, 5-nerved; palea hyaline, lanceolate, about three-quarters as long as the lemma. Upper floret hermaphrodite, equalling the sterile lemma, very turgid on one side, broadly acute, minutely apiculate: Lemma crustaceous, rather coarsely and smoothly transversely rugulose below, smooth in the upper quarter, shining, golden-brown at maturity, very convex to convex-gibbous on the back; palea almost as long, flat on the back or somewhat turgid near the base, similarly crustaceous to and a little more finely rugulose than the lemma on the back, with smooth shining curving sides embracing the flower. Lodicules firmly membranous. Grain very broadly ovate-elliptical, turgid, planoconvex, or slightly depressed on the back, about $1.75 \mathrm{~mm}$ long and $1.25 \mathrm{~mm}$ broad, the embryo about two-thirds as long, the hilum broadly oval-punctiform.

Distribution: The only additional specimen known to me is from Queensland: Leichhardt: Emerald, R. Simmons NSW 114662, 2.1908 (NSW).

\section{MICROLAENA}

Microlaena stipoides var. breviseta Vickery, var. nov.

A typo arista quam lemma inferius sterile multum breviore, arista quam lemma superius sterile aut multum breviore aut aequante, stipite lemmatis inferioris 0.1-0.5 mm longo, lemmatibus omnibus plus minusve purpurascentibus differt.

Holotype: New South Wales: Central Tablelands: Hill Top, E. Cheel NSW 115640, 8.xii.1912 (NSW).

Differs from the Type variety in the awn of the lower sterile lemma much shorter than it, the awn of the upper sterile lemma from much shorter than to equalling it, the stipe of the lower lemma $0.1-0.5 \mathrm{~mm}$ long, and the lemmas all more or less purplish.

Distribution: New South Wales: Central Tablelands, on sandstone soils.

\section{ACKNOWLEDGEMENTS}

The writer gratefully acknowledges the assistance of Dr L.A.S. Johnson and Dr Mary D. Tindale in verifying the Latin descriptions provided above. 